\title{
Pemodelan Gravity Kecamatan Dlingo Kabupaten Bantul Provinsi D.I. Yogyakarta
}

\section{Dian Novita Sari, M.Sc}

\begin{abstract}
Abstrak
Telah dilakukan penelitian dengan menggunakan metode gravity di daerah Dlingo, Kabupaten Bantul, Provinsi D.I. Yogyakarta. Penelitian ini bertujuan untuk membuat model struktur bawah permukaan tanah daerah Dlingo Kabupaten Bantul dengan menggunakan metode gravity. Metode gravity adalah metoda penyelidikan geofisika yang didasarkan pada variasi percepatan gravitasi di permukaan bumi. Pengukuran gravitasi ini disebabkan oleh adanya perbedaan dari medan gravitasi yang diakibatkan variasi massa di kerak bumi. Hasil yang didapat antara lain Sekitar 75\% daerah penelitian didominasi oleh daerah dengan variasi percepatan gravitasi tinggi dan selebihnya merupakan daerah dengan variasi percepatan gravitasi rendah, Pemodelan downward memperlihatkan bahwa dibawah permukaan tanah terdapat dua tubuh batuan yaitu batupasir dan batugamping dengan densitas 1,9g/cm3 dan 2,385 g/cm3. Di daerah tersebut terdapat patahan berupa sesar pada koordinat disekitar $\mathrm{X}=530800$ dan $\mathrm{Y}=9104200$.
\end{abstract}

Kata kunci: Pemodelan Gravity, pemodelan Downward

\section{PENDAHULUAN}

\section{Geologi regional}

Geologi Daerah Penelitian.Stratigrafi daerah Bantul dan sekitarnya tersusun oleh batuan tersier yang terdiri dari batuan sedimen klastik vulkanik, batuan gunung api, dan sedimen klastik karbonatan, serta endapan permukaan yang berumur Kuarter. Berdasarkan sifat-sifat batuan dapat diperinci menjadi tujuh formasi yaitu Formasi Yogyakarta (46\%), Formasi Sentolo (18\%), Formasi Sambipitu (3\%), Formasi Semilir Nglanggran (24\%), Formasi Wonosari (8\%), dan gumuk pasir (1\%) [4]. Struktur geologi yang berkembang di daerah Opak Pleret adalah sesar geser dan sesar normal. Di sepanjang Sungai Opak terdapat sesar normal yang berada di sepanjang hampir 40 km dari pantai selatan Jawa di mulut sungai ke arah Prambanan Kabupaten Klaten dengan arah 30 sampai 40 derajat ke timur laut. Sesar Opak memotong Yogya Low dan Wonosari Highdengan batuan andesit tua (OAF) sebagai penyusun struktur pemotongan sesar, sedangkan di timur Opak masih terdapat Formasi Semilir dan Nglanggran yang juga terlibat dalam sistem sesar.

Kondisi geologi daerah penelitian dipengaruhi oleh keberadaan 
aktivitasvulkanik dan perbukitan. Aktivitas vulkanik terbentuk dari letusan Gunungapi Merapi pada wilayah utara dan sebelah timur aktivitas Perbukitan Baturagung. Litologi daerah ini dipengaruhi oleh aktivitasGunungapi tersebut. Erupsi Gunungapi Merapi bersifat efusif yang menghasilkanaliran lava dan bahan-bahan piroklastis, sedang yang bersifat eksplosifmenghasilkan eflata (bahan lepas) dan awan panas. Adanya erupsi yang bersifatefusif dan eflata yang terjadi secara berulang-ulang dan terputus-putus (interrupted) mengakibatkan gunungapi ini mempunyai struktur berlapis (strato vulcano).

Menurut Bemmelen (1949), daerah penelitian merupakan Zone SelatanJawa Tengah yang mengalami penenggelaman di bawah permukaan laut yangdisebabkan adanya proses tektonik yang cukup kuat pada masa Pratersier dantergenang oleh perairan laut dangkal. Penenggelaman yang semula merupakan plateau tersebut diawali dari Pantai Parangtritis hingga Pantai Cilacap, tetapi tidak terjadi pada Pegunungan Karangbolong dan Bukit Selok. PegununganKarangbolong dan Bukit Selok merupakan sisa-sisa pegunungan selatan JawaTengah dan sebagai tanda bahwa pantai Selatan Jawa Tengah merupakan bagiandari rangkaian pegunungan selatan Jawa. Akibat pengangkatan tersebut, makaterbentuk sebuah graben yang merupakan semulaplateau yang terangkat, hal iniditandai adanya suatu bidang patahan (horst).

\section{DASAR TEORI}

\section{Metode Gravitasi}

Metoda gravitasi adalah metoda penyelidikan geofisika yang didasarkan pada variasi percepatan gravitasi di permukaan bumi. Pengukuran gravitasi ini dimana adanya perbedaan kecil dari medan gravitasi yang diakibatkan variasi massa di kerak bumi. Tujuan dari eksplorasi ini adalah untuk mengasosiakan variasi dari perbedaan distribusi rapat massa dan juga jenis batuan. Distribusi massa jenis yang tidak seragam dapat disebabkan oleh struktur geologi yang ada di bawah permukaan bumi. Kontribusi struktur geologi terhadap variasi nilai percepatan gravitasi di permukaan bumi sangat kecil dibandingkan dengan nilai absolutnya. Variasi nilai percepatan gravitasi tersebut tidak hanya disebabkan oleh distribusi massa jenisyang tidak merata tetapi juga dipengaruhi oleh posisi titik amat di permukaan bumi. Hal ini disebabkan oleh adanya bentuk bumi yang tidak bulat sempurna dan relief bumi yang beragam. 
Metoda ini sangat baik untuk mengetahui konfigurasi geologi bawah permukaan dengan skala yang luas berdasarkan pada perbedaan densitas tiap batuan. Teori yang mendasari metode gaya berat ini adalah teori Newton tentang Gravitasi dan teori Medan Potensial. Menurut Newton, dua massa m1 dan $\mathrm{m} 2$ yang terpisah dalam jarak $\mathrm{r}$ akan saling tarik - menarik dengan gaya yang diberikan adalah :

$$
\mathrm{F}=\frac{-G_{m 1} m_{2}}{r^{2}} r
$$

F adalah gaya pada $\mathrm{m} 2$, $\mathrm{r}$ adalah vektor satuan yang arahnya dari $\mathrm{m} 1$ dan $\mathrm{m} 2$, dan $\mathrm{G}$ adalah konstanta gravitasi universal dalam satuan SI besarnya (Nm2/Kg2) adalah 6,67 x 10-11.

$$
U(r)=-G m 1 / r
$$

U ( r ) merupakan potensial gaya berat dari massa m1. Potensial total di suatu titik bersifat penjumlahan. Maka potensial gaya berat dari suatu distribusi massa yang kontinue pada titik di luar massa tersebut merupakan suatu bentuk integral. Jika integral volume diambil untuk seluruh bumi, maka diperoleh potensial gaya berat bumi di ruang bebas, dan medan gaya berat didapatkan dengan menurunkan potensial tersebut.
Faktor - faktor yang mempengaruhi besar kecilnya harga gravitasi pada suatu titik pengamatan adalah :

1. Posisi garis lintang.

2. Kedudukan matahari dan bulan terhadap bumi (pasang surut)

3. Elevasi (ketinggian titik pengamatan)

4. Keadaan topografi di sekitar titik pengukuran.

5. Variasi rapat massa batuan di bawah permukaan

\section{Konversi dan Koreksi dalam Metoda Gravity}

Pengukuran gravitasi dimaksudkan untuk mengetahui harga graviatasi suatu titik pengamatan relatif terhadap suatu titik acuan. Dengan demikian harga gravitasi titik pengamatan dalam kerangka referensi yang sama dengan harga gravitasi titik acuan dapat diketahui. Untuk mendapatkan harga gravitasi hasil pengukuran dari titik pengamatan perlu melakukan langkah langkah sebagai berikut: 
1. Konversi skala pembacaan ke percepatan gravitasi.

2. Koreksi pasang surut bumi padat.

3. Koreksi drift (apungan)

4. Kalibrasi pengukuran.

\section{METODE PENELITIAN}

Pemodelan berdasarkan respon medan gravitasi terhadap struktur persesaran yang menjadi target penelitian hingga didapat model dengan geometri, ketebalan, struktur pembentuk batuan, dan struktur perlapisan yang mempunyai respon medan gravitasi model sesuai dengan respon medan gravitasi yang diperoleh dari data pengukuran.

\section{HASIL DAN PEMBAHASAN}

Peta ABL atau Peta Anomali Bouger Lengkap (Gambar 1) dikelompokkan menjadi tiga daerah berdasarkan skala warna yaitu daerah dengan variasi percepatan gravitasi rendah, sedang dan tinggi. Daerah yang termasuk kedalam daerah dengan variasi percepatan gravitasi rendah adalah daerah dengan nilai 132,5 mGal hingga 136,67 mGal yang ditunjukkan dengan warna ungu hingga biru muda. Sedangkan daerah yang termasuk ke dalam daerah dengan variasi percepatan gravitasi sedang adalah daerah dengan nilai > 136,67 mgal hingga 140,33 mGal yang ditunjukkan dengan warna biru muda hingga kuning. Daerah yang termasuk ke dalam daerah dengan nilai variasi percepatan gravitasi tinggi adalah daerah yang mempunyai nilai > 140,33 mGal hingga $145 \mathrm{mGal}$ yang ditunjukkan oleh warna kuning hingga merah.

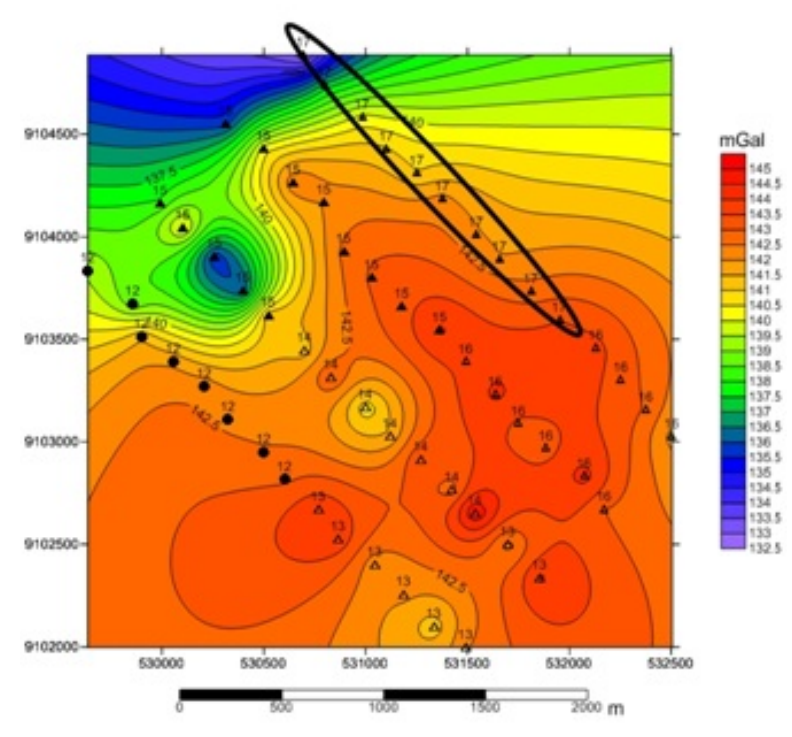

Gambar 1. Peta Anomali Bouger Lengkap.

Peta upward (Gambar 2) merupakan peta Anomali Bouger Lengkap (ABL) yang mengalami pengangkatan dengan tujuan untuk menghilangkan pengaruh bolderbolder atau bongkahan kecil dari variasi percepatan gravitasi dibawah permukaan tanah pada peta guna melihat peta daerah penelitian dalam cakupan regional. Peta upward (Gambar 2) memperlihatkan 
perubahan warna pada tiap ketinggian yang berbeda.

Peta Downward (Gambar 3) menggambarkan daerah penelitian secara lokal. Berdasarkan skala warna, maka warna ungu hingga hijau tua merupakan daerah dengan variasi percepatan gravitasi rendah, sedangkan warna hijau tua hinnga kuning merupakan daerah dengan variasi percepatan gravitasi sedang sedangkan daerah dengan warna kuning hingga merah merupakan daerah dengan nilai variasi percepatan gravitasi yang tinggi.

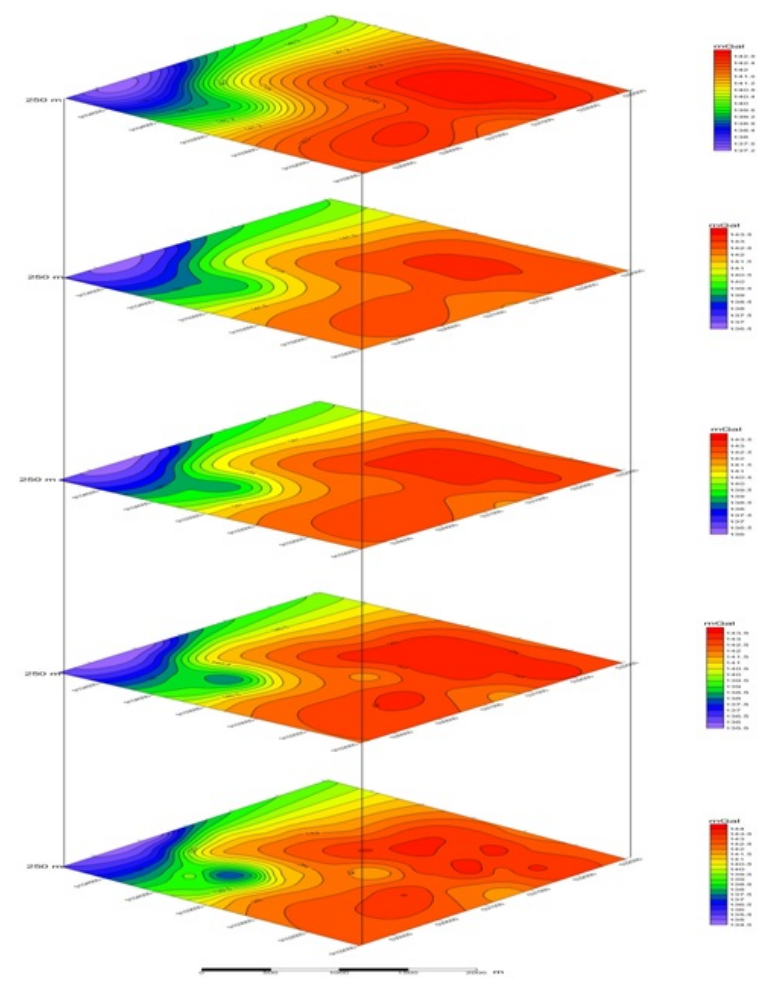

Gambar 2. Peta upward continuation

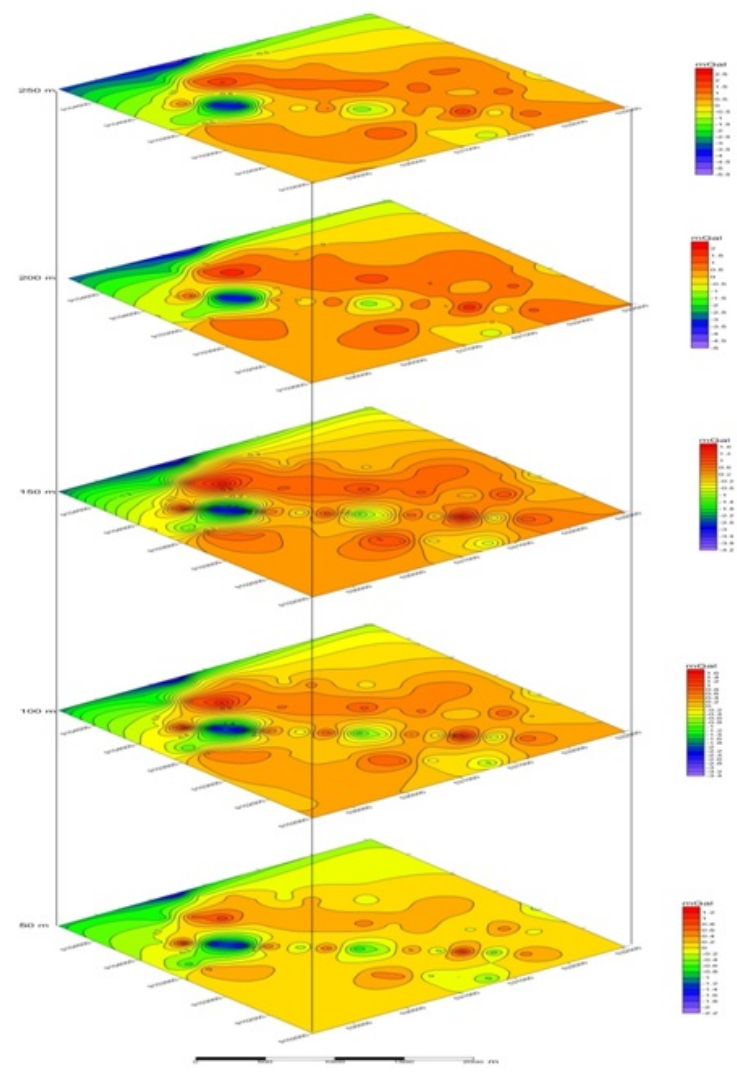

Gambar 3. Peta Downward continuation

Pemodelan downward (Gambar 4.a) merupakan gambaran atau asumsi mengenai bentuk tubuh batuan serta struktur geologi dibawah permukaan daerah penelitian. Berdasarkan table densitas batuan (Telford,1990) ,warna biru dengan densitas 1,9g/cm3 diindikasikan sebagai batugamping. Di atas batugamping tersebut diendapkan batupasir dengan densitas 2,385 g/cm3..

Sayatan dilakukan pada peta downward $250 \mathrm{~m}$ (gambar 4.b) dengan 
koordinat sekitar $\mathrm{X}=530000$ hingga $X=531000 \quad$ dan $\quad Y=9103500 \quad$ hingga $\mathrm{Y}=9104500$. Sayatan pada gambar 4.b ditandai dengan warna hitam tebal. Pada pemodelan terlihat adanya garis yang melengkung ke atas dan ke bawah pada gambar 4.a diasumsikan bahwa di daerah ada patahan yang diakibatkan oleh sesar turun. Sesar yang dimaksud ditandai dengan warna garis hijau tebal pada gambar 4.a. Jika dilihat pada peta downward $250 \mathrm{~m}$ (gambar 4.b), maka sesar diperkirakan berada pada koordinat $\mathrm{X}=530800$ dan $\mathrm{Y}=9104200$ yang ditandai dengan warna garis ungu putusputus yang dilingkari garis ungu.
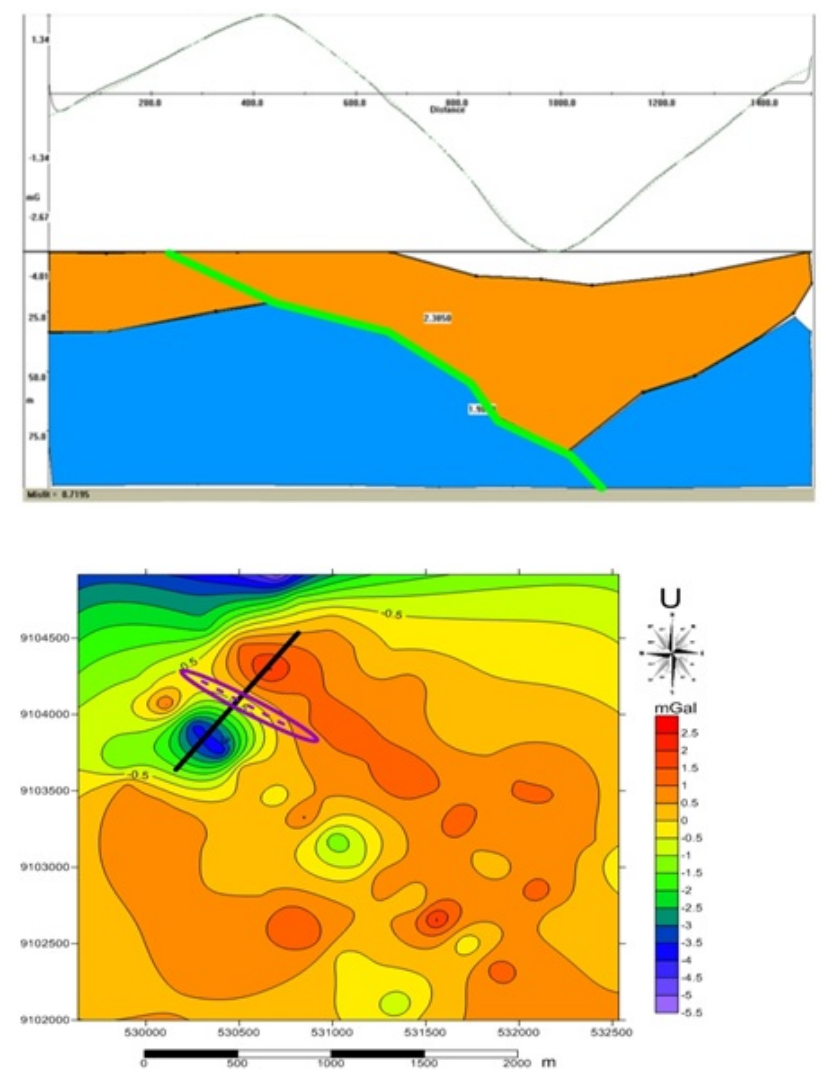

Gambar 4.a. gambar model bawah permukaan daerah penelitian b. peta sayatan downward $250 \mathrm{~m}$.

\section{KESIMPULAN}

Hasil yang didapat antara lain Sekitar 75\% daerah penelitian didominasi oleh daerah dengan variasi percepatan gravitasi tinggi dan selebihnya merupakan daerah dengan variasi percepatan gravitasi rendah, Pemodelan downward memperlihatkan bahwa dibawah permukaan tanah terdapat dua tubuh batuan yaitu batupasir dan batugamping dengan densitas $1,9 \mathrm{~g} / \mathrm{cm} 3$ dan 2,385 $\mathrm{g} / \mathrm{cm} 3$. Di daerah tersebut terdapat patahan berupa sesar pada koordinat disekitar $\mathrm{X}=530800$ dan $\mathrm{Y}=9104200$.

\section{DAFTAR PUSTAKA}

- Bemmelen, R.W. van., 1949. The Geology of Indonesia,Belanda: The Hague

- Blakely, R.J. 1995. Potential Theory in Gravitasi and Magnetic Applications, Cambridge University Press, USA. 
- Santoso, Joko (2002), Pengantar Teknik Geofisika, Bandung: Penerbit ITB

- Telford, W.M, Geldart L.P, Sheriff R.E, Applied Geophysics, Australia: Press Syndicate of The University of Cambridge 